\title{
BULLETIN
}

doi: 10.2478/sho-2020-0011

\section{YEARS OF POZNAŃ ECONOMIC HISTORY}

2020 is a jubilee year for the Department of Economic History. The Department of Economic History associates the beginning of its hundred-year history with the appointment, from 1 July 1920, of prof. Jan Rutkowski (1886-1949) as the first head of the Chair of Economic History at the Faculty of Law and Economics of the University of Poznań, prof. Jan Rutkowski [AUAMP, 208/49: 422].

Prof. Jan Rutkowski is considered one of the founders and the first promoters of economic history in Poland. Together with prof. Franciszek Bujak led to the separation of historical and economic research as an independent academic discipline. He was also involved in work for didactics and the organization of higher education. He promoted teamwork [Graban M., Błażejczyk-Majka L. 2019]. It is worth emphasizing that prof. Jan Rutkowski belonged to a group of scientists who had been invited to work at the Faculty of Philosophy by the University Commission established to organize the Polish university in Poznan [1918 listopad 18, Poznań... 1973]. He also participated, as a delegate of the Faculty of Law and Economics, in the first sessions of the senate of the newly established University of Poznań [Uniwersytet Poznański: skład osobowy... 1920: 3, 15; Protokoły posiedzeń.. 2019: 3-38].

The establishment of the Chair of Economic History at the University of Poznan was preceded by prof. Jan Rutkowski conducting, from the first semesters of the newly established University, seminars on economic history and obligatory lectures on the economic history of Poland [Uniwersytet Poznański: spis wykładów... 1919: 47-50; Uniwersytet Poznański: spis wykładów... 1920: 8]. As mentioned earlier, from 1920 prof. Jan Rutkowski took the position of the chair of an independent department. In accordance with the organizational structure of the University of Poznan in force in the interwar period, he was the director of an independent research institution - Seminar. Initially, it was an economic seminar at the Faculty 
of Law and Economics [Uniwersytet Poznański: sktad osobowy... 1921: 34], which a year later took the name of 'the Seminar on Economic History and Old Polish Law' [Uniwersytet Poznański: skład osobowy... 1923: 24]. From 1931, the institution was called 'the Seminar on Economic History and Old Polish Law, and the History of Law of Western Europe'. Its members included prof. Jan Rutkowski, prof. Zygmunt Wojciechowski, prof. Marian Jedlicki and two assistants [Uniwersytet Poznański: skład osobowy... 1932: 24]. This institution developed so much that in 1937 it was divided [Uniwersytet Poznański: skład osobowy... 1938: 51]. Finally, as part of the Economic History Seminar on the eve of the war, under the supervision of prof. Jan Rutkowski were employed: Dr. Guntram Rolbiecki, MA Janusz Deresiewicz and MA Władysław Rusiński [Uniwersytet Poznański: skład osobowy... 1939: 50-51].

In the interwar period, prof. Jan Rutkowski and his students developed extensive research on the economic history of Polish lands from the $15^{\text {th }}-20^{\text {th }}$ centuries, with particular emphasis on the history of rural areas. These works were characterized by emphasizing economic factors in the processes of shaping and development of Polish society [Czubiński A. 1972: 163]. In 1925, prof. Jan Rutkowski also presented the concept of synthesis in economic history [Rutkowski J. 1925]. He is recognized as a pioneer in the use of quantitative methods in the development of historical material in the case of research on society and economy [Topolski J. 1986: 193]. Based on such assumptions, a research unit was established in Poznań, which, next to the Chair of Economic History at the Jan Kazimierz University in Lviv, quickly gained the status of an important research center on economic history in Poland [Janicki T. 2019]. The culmination of these efforts was the establishment in 1931 by prof. Jan Rutkowski and prof. Franciszek Bujak of the scientific journal entitled Roczniki Dziejów Spotecznych $i$ Gospodarczych [Annals of Social and Economic History], published initially in Lviv, and from 1945 in Poznań [Roczniki Dziejów... 1931]. Dynamic scientific development of the Department named 'The economic history seminar' was interrupted by the outbreak of World War II. During the German occupation of Poznan, prof. Jan Rutkowski, like most professors of the University of Poznań, was displaced to the General Government [Janicki, 2019]. During World War II, he actively participated in the work of the secret University of the Western Territories [Łuczak C. 1972: 326-9].

After the end of hostilities and the return of prof. Jana Rutkowski to Poznan, the Economic History Seminar continued its activity as a Chair at the Faculty of Law and Economics [Kronika Uniwersytetu... 1958: 
140-4]. At the same time, from 1948, the Chair of Economic History was part of the interdepartmental Institute of History, from which in the academic year 1950/1951 the Complex of Historical Chairs was created [Markiewicz W. 1972:. 388]. After the death of prof. Jan Rutkowski, the curator of the Chair of Economic History was prof. Zygmunt Wojciechowski. In 1950, as a result of changes in the structure of the University, the unit was transferred to the Faculty of Humanities, where, as the Department of Economic History, it was part of the Chair of Polish History, headed by prof. Gerard Labuda. From the beginning of the 1951/1952 academic year, the Chair of Economic History was established within the Complex of Historical Chairs. The management of the Department (later the Chair) was taken over in 1950 by prof. Stanisław Szczotka, and after his death in 1954, prof. Władysław Rusiński [AUAMP,. Call No. 191/44; AUAMP, Call No. 191/48; AUAMP. Call No. 208/48; Kronika Uniwersytetu... 1958: 373-4, 385-7; Janicki T. 2019].

The following years brought structural changes within the entire University. In 1956, the Complex of Historical Chairs operating at the Faculty of Philosophy and History was transformed into the Historical Institute, and the Chair of Economic History became part of it [Matusik P. 2019]. In 1957, the Senate of the University of Adam Mickiewicz decided to divide the chair and create two new ones with the same name, headed by Prof. Władysław Rusiński and prof. Janusz Deresiewicz, the first of which remained at the Faculty of Philosophy and History, and the second was transferred to the Faculty of Law [Kronika Uniwersytetu... 1960: 38, 120-1]. As part of the Chair of Economic History headed by prof. Rusiński, two departments have been distinguished: the Economic History of Poland and the General Economic History [Kronika Uniwersytetu... 1969: 204-8; Janicki, 2019]. Under the influence of the March events of 1968, further changes took place in Polish higher education. On September 1, 1969, the name of the Historical Institute was changed to the Institute of History, and its chairs were renamed as departments (Matusik, 2019). The previous Chair of Economic History was transformed into the Department of Economic History. Since 2019, the Department of Economic History belongs to the structures of the Faculty of History at the University of Adam Mickiewicz [Janicki T. 2019].

The organizational changes presented above in the perspective of 100 years of history undoubtedly influenced the directions of scientific research carried out as part of the Seminar/Chair or Department of Economic History. Maintaining the continuity of scientific work in the face of orga- 
nizational changes in the entire higher education system in Poland and at the Adam Mickiewicz University in Poznan itself was undoubtedly due to the successive heads of this unit [Janicki T. 2019]. After the initiator of the establishment of the Chair of Economic History, prof. Jan Rutkowski, his students played a large role in this process: Prof. Władysław Rusiński and prof. Czesław Łuczak [Błazejczyk-Majka L. 2019; Jaroszyk-Pawlukiewicz J. 2019]. After them, the Department of Economic History was headed by prof. Stefan Kowal (1992-2007) and prof. Roman Macyra (2007-2017). In 2017, the management of the Department of Economic History was taken by prof. Tadeusz Janicki.

For most of the hundred-year history, the Chair and then the Department of Economic History saw a systematic increase in the number of employees, which reached its peak at the beginning of the 21st century. The following professors and doctors were professionally associated with the Chair and then the Department of Economic History: prof. Janusz Deresiewicz, prof. Witold Szulc, prof. Jerzy Topolski, prof. Bożena Górczyńska-Przybyłowicz, Dr. Urszula Cynalewska, Dr. Teresa Dohnal, Dr. Tadeusz Filipiak, Dr. Marek Żurowski, Dr. Andrzej Dmitrzak and Dr. Anna Bitner-Nowak, Dr. Zdzisława Szymańska-Chlebowska, Dr. Regina Pacanowska, Dr. Przemysław Pluciński, Dr. Miron Urbaniak, Dr. Marcin Graban and MA Zdzisława Drążkowska and MA Elżbieta Sparażyńska. At present, the academic staff of the Department consists of: prof. Tadeusz Janicki, prof. Roman Macyra, prof. Lucyna Błażejczyk-Majka, prof. Jan Miłosz, Dr. Joanna Jaroszyk-Pawlukiewicz and Dr. Jakub Kujawa [see Janicki T. 2019].

Depending on the composition and size of the team, extensive research in this area of knowledge was carried out within the Chair/Department of Economic History. Nevertheless, the main research areas of the Chair/ Department of Economic History include the history of rural areas and agriculture, the economic and social history of Wielkopolska, the German occupation of Poland and Europe during World War II, Polish-German economic relations and the economic history of Germany. Since the beginning of the 1990s, the research areas have been significantly expanded to include selected issues related to the social and economic history of Poland, Europe and the world, local government administration and the analysis of methodological problems related to the use of quantitative methods in historical research [see Janicki T. 2019].

Numerous publications were obviously a manifestation of the academic activity of the employees of the Chair/Department of Economic 
History. However, academic conferences organized within this unit, which gathered economic historians and representatives of related disciplines from various Polish research centers, should be emphasized. One of the most significant is the conference on 4-5 June 1968 devoted to the history of the food industry in Poland in the $19^{\text {th }}$ and $20^{\text {th }}$ centuries [Kronika Uniwersytetu... 1969: 205]. In the face of social and economic changes, the conference entitled: "From Grabski to Balcerowicz. Monetary systems in the Polish economy", which was organized on 2-3 December 1994, played an important role [Kowal S. 2019]. A manifestation of the opening of the employees of the Department of Economic History to interdisciplinary cooperation were undoubtedly the conferences under the title "Money and banks..." organized in cooperation with the National Museum in Poznan in 2008-2014, which resulted in a series of publications under the title "Studia nad Dziejami Pieniądza i Bankowości w Polsce" ["Studies on the History of Money and Banking in Poland"] [Pieniadz i banki... 2009, 2012, 2017, 2018].

The Chair/Department of Economic History in Poznan from the very beginning of its existence took an active part in consolidating the achievements of this discipline in Poland and its promotion abroad. As mentioned earlier, one of the first manifestations of this type of activity is the publication of Roczniki z Dziejów Społecznych i Gospodarczych, which are now published by the Tadeusz Manteuffel Institute of History of the Polish Academic of Sciences. On the other hand, in Poznań, since 1967 the journal Studia Historiae Oeconomicae created a year earlier by prof. Czesław Łuczak and prof. Jerzy Topolski, has been published. Its aim has been to overcome language barriers and present the scientific achievements of Polish economic and social historians on a global scale. For a long time this yearbook was the only periodical of its kind in socialist countries to publish articles in congressional languages from the very first issue. Throughout its existence, this journal is inextricably linked with the Department of Economic History in Poznań [Graban M., Janicki T. 2019].

Changes in the organizational structure and areas of academic interest of the Department of Economic History in Poznan, which took place in its hundred-year history, are a good example of the process of searching for the place of economic history in the modern science. It is to be hoped that in the face of successive crises of both local and global importance, the development of social and economic research in a historical perspective will contribute to a better understanding of the world around us. 


\section{REFERENCES}

\section{Archive Materials}

Archiwum Uniwersytetu im. Adama Miciewicza w Poznaniu, AUAMP, Call No. 191/44, Akta osobowe: Wydziat Filozoficzno-Historyczny, Rusiński Wtadystaw.

Archiwum Uniwersytetu im. Adama Miciewicza w Poznaniu, AUAMP, Call No. 191/48, Akta osobowe: Wydziat Filozoficzno-Historyczny, Szczotka Stanistaw.

Archiwum Uniwersytetu im. Adama Miciewicza w Poznaniu, AUAMP, Call No. 208/48, Akta osobowe: Wydziat Prawa, Rusiński Wtadystaw.

Archiwum Uniwersytetu im. Adama Miciewicza w Poznaniu, AUAMP, Call No. 208/49, Akta osobowe: Wydziat Prawa, Rutkowski Jan.

\section{Literature}

1918 listopad 18, Poznań. Sprawozdanie z II posiedzenia Komisji Uniwersyteckiej (1973), Czubiński A., Kujawska M. (eds.), Źródła do dziejów Uniwersytetu im. Adama Mickiewicza w Poznaniu. T. 1, Organizacja i rozwój uczelni od listopada 1918 roku do inauguracji w maju 1919 roku, Wydawnictwo Uniwersytetu im. Adama Mickiewicza w Poznaniu, Poznań, 19-22.

Błażejczyk-Majka L. (2019), Władystaw Rusiński (1911-1986), [in:] Dobosz J., KonieczkaŚliwińska D., Kościelniak K., Matusik P., (eds.), Historia na Uniwersytecie Poznańskim. Od Seminarium Historycznego do Instytutu Historii (1919-2019). Uniwersytet im. Adama Mickiewicza w Poznaniu, Instytut Historii, Poznań, 109-110.

Czubiński A. (1972), Dzieje Uniwersytetu Poznańskiego w latach 1918-1939, [in:] Grot Z.H. (ed.), Dzieje Uniwersytetu im. Adama Mickiewicza: 1919-1969, Wydawnicytwo Naukowe UAM (Seria Dzieje UAM: nr 7), Poznań, 59-302.

Graban M., Błażejczyk-Majka L. (2019), Jan Rutkowski (1886-1949), [in:] Balbuza, K., Dobosz J., Konieczka-Śkiwińska D., Kościelniak K., Matusik P. (eds.), Historia na Uniwersytecie Poznańskim. Od Seminarium Historycznego do Instytutu Historii (1919-2019). Uniwersytet im. Adama Mickiewicza w Poznaniu, Instytut Historii UAM, Poznań, 111-113.

Graban M., Janicki T. (2019), Studia Historiae Oeconomicae, [in:] Balbuza, K., Dobosz J., Konieczka-Śkiwińska D., Kościelniak K., Matusik P. (eds.), Historia na Uniwersytecie Poznańskim. Od Seminarium Historycznego do Instytutu Historii (1919-2019). Uniwersytet im. Adama Mickiewicza w Poznaniu, Instytut Historii UAM, Poznań, 304-305.

Janicki T. (2019), Zakład Historii Gospodarczej, [in:] Balbuza, K., Dobosz J., KonieczkaŚkiwińska D., Kościelniak K., Matusik P. (eds.), Historia na Uniwersytecie Poznańskim. Od Seminarium Historycznego do Instytutu Historii (1919-2019). Uniwersytet im. Adama Mickiewicza w Poznaniu, Instytut Historii UAM, Poznań, 146-147.

Jaroszyk-Pawlukiewicz J. (2019), Czestaw Łuczak (1922-2002), [in:] Balbuza K., Dobosz J., Konieczka-Śkiwińska D., Kościelniak K., Matusik P. (eds.), Historia na Uniwersytecie Poznańskim. Od Seminarium Historycznego do Instytutu Historii (1919-2019). Uniwersytet im. Adama Mickiewicza w Poznaniu, Instytut Historii UAM, Poznań, 80-82.

Kowal S. (2019), Konferencja „Od Grabskiego do Balcerowicza. Systemy pieniężne w gospodarce polskiej", [in:] Balbuza K., Dobosz J., Konieczka-Śkiwińska D., Kościelniak K., Matusik P. (eds.), Historia na Uniwersytecie Poznańskim. Od Seminarium Historycznego do Instytutu Historii (1919-2019). Uniwersytet im. Adama Mickiewicza w Poznaniu, Instytut Historii UAM, Poznań, 335-336.

Kronika Uniwersytetu im. Adama Mickiewicza w Poznaniu za lata akademickie 1965/66-1967/68 za Rektoratu Prof. Dra Czesława Łuczaka (1969), Łuczak C., Wisłocki J., Miśkiewicz B., Wójciak W. (eds.), Uniwersytet Poznański, Poznań. 
Kronika Uniwersytetu im. Adama Mickiewicza w Poznaniu za rok akademicki 1957/1958 za Rektoratu Prof. Dra Alfonsa Klafkowskiego i inauguracja roku akademickiego 1958/1959 w dniu 1 października 1958 r. (1960), Łopatka A. (ed.), Państwowe Wydawnictwo Naukowe, Poznań.

Kronika Uniwersytetu Poznańskiego za lata akademickie 1945-1954/55 (1958), Deresieiwcz J. (ed.), Państwowe Wydawnictwo Naukowe, Poznań:

Łuczak C. (1972), Uniwersytet Poznański w latach hitlerowskiej okupacji, [in:] Grot, Z.H. (ed.), Dzieje Uniwersytetu im. Adama Mickiewicza: 1919-1969, Wydawnicytwo Naukowe UAM, Poznań, 303-344.

Markiewicz W. (1972), Dzieje Uniwersytetu im. Adama Mickiewicza w Poznaniu w latach 1945-1958, [in:] Grot, Z.H. (ed.), Dzieje Uniwersytetu im. Adama Mickiewicza: 1919-1969. Wydawnicytwo Naukowe UAM, Poznań, 345-450.

Matusik P. (2019), Dzieje Instytutu Historii UAM, [in:] Balbuza, K., Dobosz J., Konieczka-Śliwińska D., Kościelniak K., Matusik P. (eds.), Historia na Uniwersytecie Poznańskim. Od Seminarium Historycznego do Instytutu Historii (1919-2019). Uniwersytet im. Adama Mickiewicza w Poznaniu, Instytut Historii UAM, Poznań, 9-15.

Pieniądz i banki na Pomorzu (2017), Garbaczewski W., Macyra R. (eds.), Muzeum Narodowe w Poznaniu (Studia nad Dziejami Pieniądza i Bankowości w Polsce: t. 3), Poznań.

Pieniądz i banki na Śląsku (2012), Garbaczewski W., Macyra R. (eds.), Muzeum Narodowe w Poznaniu (Studia nad Dziejami Pieniądza i Bankowości w Polsce: t. 2), Poznań.

Pieniądz i banki w Małopolsce (2018), Macyra R., Garbaczewski W., Bartkowiak Z. (eds.), Muzeum Narodowe w Poznaniu (Studia nad Dziejami Pieniądza i Bankowości w Polsce: t. 4), Poznań.

Pieniądz i banki w Wielkopolsce (2009), Garbaczewski W., Macyra R. (eds.), Muzeum Narodowe w Poznaniu (Studia nad Dziejami Pieniądza i Bankowości w Polsce: t. 1), Poznań.

Protokoły posiedzeń Senatu Uniwersytetu Poznańskiego 1919-1939. Tom I. (2019), Domalanus A., Mamczak-Gadkowska I., Sak M., Wysokińska A. (eds.), Wydawnictwo Naukowe Uniwersytetu UAM (Źródła do Dziejów Uniwersytetu im. Adama Mickiewicza w Poznaniu), Poznań.

Roczniki Dziejów Społecznych i Gospodarczyc. T. I (1931), Bujak F., Rutkowski, J. (eds.), Instytut Popierania Polskiej Twórczości Naukowej, Lwów.

Rutkowski J. (1925), Zagadnienie syntezy w historii gospodarczej, [in:] Pamiętnik IV Zjazdu Historyków Polskich w Poznaniu 6-8 grudnia 1925, I, Referaty, Polskie Towarzystwo Historyczne, Lwów, sekcja IV/1-7.

Topolski J. (1986), Jan Rutkowski (1886-1949): o nowy model historii, Panstwowe Wydawnictwo Naukowe, Warszawa.

Uniwersytet Poznański: skład osobowy:rokakademicki 1919/1920 (1920), Uniwersytet Poznański, Poznań.

Uniwersytet Poznański: skład osobowy: rok akademicki 1920/21 (1921), Uniwersytet Poznański, Poznań.

Uniwersytet Poznański: skład osobowy: rok akademicki 1922/23 (1923), Uniwersytet Poznański, Poznań.

Uniwersytet Poznański: skład osobowy: rok akademicki 1931/32 (1932), Uniwersytet Poznański, Poznań.

Uniwersytet Poznański: skład osobowy: rok akademicki 1937/38 (1938), Uniwersytet Poznański, Poznań.

Uniwersytet Poznański: skład osobowy: rok akademicki 1938/39 (1939), Uniwersytet Poznański, Poznań. 
Uniwersytet Poznański: spis wykładów w pótroczu jesiennym 1919 (1919), Uniwersytet Poznański, Poznań.

Uniwersytet Poznański: spis wykładów w pótroczu zimowem 1920 (1920), Uniwersytet Poznański, Poznań.

Lucyna Błażejczyk-Majka, dr hab., prof. UAM, affiliated with the Department of Economic History. Scientific interests include history of economics, numerical methods in history, econometrics, agricultural economics, economic efficiency, contemporary sources of information. 